\title{
Shotgun Metagenomic Analysis for Mucilage in the Surface Waters of The Çanakkale Strait (Dardanelles): Metabolic Diversity, Microbial Community Structure and Antibiotic Resistance Genes
}

\author{
Sevdan YILMAZ1* ${ }^{*} \quad$ Dilek KAHRAMAN YILMAZ ${ }^{2} \quad$ Ekrem Şanver ÇELIK $^{2} \quad$ Mehmet Ali KUCUKER $^{3}$ \\ ${ }^{1}$ Department of Aquaculture, Faculty of Marine Sciences and Technology, Çanakkale Onsekiz Mart University, Çanakkale 17100, Turkey \\ ${ }^{2}$ Department of Marine Biology, Faculty of Marine Sciences and Technology, Cnakkale Onsekiz Mart University, Canakkale 17100, Turkey \\ ${ }^{3}$ İzmir Institute of Technology, Faculty of Engineering, Department of Environmental Engineering, Gülbahçe Campus 35430 Urla - İzmir / Turkey
}

How to cite: Yilmaz, S., Kahraman Yilmaz, D., Çelik, E.Ş. \& Kucuker, M.A. (2021). Shotgun Metagenomic Analysis for Mucilage in the Surface Waters of The Çanakkale Strait (Dardanelles): Metabolic Diversity, Microbial Community Structure and Antibiotic Resistance Genes. J. Anatolian Env. and Anim. Sciences, 6(4), 717-726.

Atıf yapmak için: Yilmaz, S., Kahraman Yilmaz, D., Çelik, E.Ş. \& Kucuker, M.A. (2021). Çanakkale Boğazı Yüzey Sularındaki Müsilaj İçin Shotgun Metagenomik Analizi: Metabolik Çeşitlilik, Mikrobiyal Topluluk Yapısı ve Antibiyotik Direnç Genleri. Anadolu Çev. ve Hay. Dergisi, 6(4), 717-726.

: https://orcid.org/0000-0002-4809-5809 D: https://orcid.org/0000-0002-9626-5446 (iD): https://orcid.org/0000-0003-4514-457X (iD): https://orcid.org/0000-0001-9648-8925
Abstract: In this study, we used shotgun metagenome sequencing to examine the metabolic diversity, microbial community structure and diverse antimicrobial resistance genes of mucilage in the surface waters of the Çanakkale Strait (Dardanelles). Mucilage samples were collected in April 2021 from the three different stations of the Dardanelles. The dominant microbial communities at the phylum level were Bacteroidetes $(20.06 \%)$, Proteobacteria $(13.68 \%)$, Verrucomicrobia $(6.25 \%)$, Planctomycetes (3.02\%) and Cyanobacteria (2.5\%). Metabolic pathway analysis using KEGG (Kyoto Encyclopedia of Genes and Genomes) revealed that most of the genes of mucilage samples were involved in unclassified (73.86\%) followed by metabolism (14.45\%), genetic information processing $(4.16 \%)$, environmental information processing $(2.57 \%)$, cellular processing $(1.88 \%)$, human diseases $(1.61 \%)$, and organismal systems (1.47\%). The $d f r A 3$ gene was the most prevalent (20.36\%) followed by CRP (18.17\%), PmrE (14.92\%), rров2 (11.17\%), SoxR (7.49\%), AbeS (6.83\%), baeR (5.22\%), PmrF (3.70\%), dfra22 (2.20\%), dfrA26 (1.76\%), dfrA20 (1.63\%), golS (1.26\%), CAT (1.03\%), mtrA (1.01\%), TMB-l (0.64\%), novA $(0.64 \%), d f r K(0.59 \%)$, vanXB $(0.48 \%), d f r G(0.39 \%)$, FosC2 (0.31\%), and MexA $(0.20 \%)$ genes. Antibiotic resistance gene (ARG) types mainly included the resistance genes of multidrug $(40.19 \%$ ), trimethoprim $(26.93 \%)$, polymyxin $(18.62 \%)$, rifamycin $(11.17 \%)$, chloramphenicol $(1.03 \%)$, aminocoumarin $(0.64 \%)$, beta-lactamase $(0.64 \%)$, fosfomycin $(0.31 \%)$, and vancomycin $(0.48 \%)$. Antibiotic-resistant bacteria in mucilage can adhere to human skin during swimming, fishing, water sports etc., enter the body through the nose and mouth, and transfer genetic information to the bacteria in contact areas in the human body. Therefore, this situation is risky in public health, and necessary precautions should be taken.

In the light of these findings, it has been observed that there is a need for more detailed studies in the future.

Keywords: Antibiotic, ARG, marine aggregates, metagenome, mucilage, public health.

\section{Çanakkale Boğazı Yüzey Sularındaki Müsilaj İçin Shotgun Metagenomik Analizi: Metabolik Çeşitlilik, Mikrobiyal Topluluk Yapısı ve Antibiyotik Direnç Genleri}

\begin{abstract}
Öz: Bu çalışmada Çanakkale Boğazı yüzey sularındaki müsilajın metabolik çeşitliliğini, mikrobiyal topluluk yapısını ve çeșitli antimikrobiyal direnç genlerini incelemek için shotgun metagenom dizilimi kullanılmıştır. Nisan 2021'de Çanakkale Boğazı'nın üç farklı istasyonundan müsilaj örnekleri toplanmıştır. Filum düzeyinde baskın mikrobiyal topluluklar Bacteroidetes $(\% 20,06)$, Proteobacteria $(\% 13,68)$, Verrucomicrobia $(\% 6,25)$, Planctomycetes $(\% 3,02)$ ve Cyanobacteria $(\% 2,5)$ olarak belirlenmiştir. KEGG (Kyoto Genler ve Genomlar Ansiklopedisi) kullanılarak yapılan metabolik yol analizi, müsilaj örneklerinin genlerinin çoğunun sınıflandırılmamış $(\% 73,86)$, ardından sırasıyla metabolizma $(\% 14,45)$, genetik prosesler $(\% 4,16)$, çevresel prosesler $(\% 2,57$, hücresel prosesler $(\% 1,88)$, insan hastalıkları $(\% 1,61)$ ve organizma sistemleri $(\% 1,47)$ ile ilişkili olduğunu göstermiştir. dfrA3 geni baskın çıkmıştır $(\% 20,36)$, ardından sırasıyla CRP $(\% 18,17), \operatorname{PmrE}(\% 14,92)$, rpoB2 (\%11,17), SoxR (\%7,49), AbeS (\%6,83), baeR (\%5,22), PmrF $(\% 3,70)$, dfrA22 (\%2,20), dfra26 $(\% 1,76)$, dfrA20 (\%1,63), golS $(\% 1,26)$, CAT $(\% 1,03)$, mtrA $(\% 1,01)$, TMB-1 $(\% 0,64)$, novA $(\% 0,64)$,
\end{abstract}


$d f r K(\% 0,59)$, vanXB $(\% 0,48), d f r G(\% 0,39)$, FosC2 $(\% 0,31)$ ve MexA $(\% 0,20)$ genleri yer almıştır. Antibiyotik direnç geni (ARG) tipleri, temel olarak çoklu ilaç direnci $(\% 40,19)$, trimetoprim $(\% 26,93)$, polimiksin $(\% 18,62)$, rifamisin $(\% 11,17)$, kloramfenikol $(\% 1,03)$, aminokumarin $(\% 0,64)$, betalaktamaz $(\% 0,64)$, fosfomisin $(\% 0,31)$ ve vankomisin $(\% 0,48)$ direnç genleri olarak belirlenmiştir. Müsilaj yapıdaki antibiyotik dirençli bakteriler yüzme, su sporları, balıkçılık ve benzeri faliyetler sırasında insan derisine tutunabilir, burun ve ağız yolu ile vücudumuza girebilir ve genetik bilgiyi insan vücudunda temas ettiği bölgelerdeki bakterilere aktarabilir. Bu durum halk sağlığı açısıdan riskli olup gerekli önlemlerin alınması gerekmektedir. Bu bulgular ışı̆̆ında gelecekte daha detaylı çalışmalara ihtiyaç olduğu gözlemlenmiştir.

Anahtar kelimeler: Antibiyotik, ARG, deniz agregatları, halk sağlı̆̆ı, metagenom, müsilaj.

\section{INTRODUCTION}

Domestic and industrial factors have started to pollute the environment more due to the increase in the human population. As a result of increasing pollution in the natural environment, climate change and global warming, ecosystem balances have deteriorated, and ecological problems have arisen. Among these problems, the incident known as mucilage occurred first time in 1729 when it caused the congestion of fishing nets in the Adriatic Sea (Fonda-Umani et al., 1989). Danovaro et al. (2009) investigated the relationship between climate change and the frequency of mucilage formation in the Mediterranean in the last 200 years. They determined that it has increased exponentially over the years.

Intense mucilage formation was first recorded in Turkey between 2007 and 2008 in the Sea of Marmara (Aktan et al., 2008; Tüfekçi et al., 2010; Balkis et al., 2011) and in the Dardanelles Strait (Yentur et al., 2013). In the first two quarters of 2021, mucilage reached dimensions that would adversely affect fishery industry, tourism and social life.

Mucilage is a dense and highly viscous structure consisting of polymeric substances and extracellular polysaccharides produced, secreted or leaked by various marine microorganisms such as diatoms, dinoflagellate, cyanobacteria and bacteria, especially in stressful situations; and it is a substance with hydrogel properties, rich in dissolved and polymeric organic matter (Giani et al., 2005; Danovaro et al., 2009; Öztürk et al., 2021). Conducted studies have shown that the content of mucilage can consist of many different species and sizes of sea creatures such as viruses, bacteria, phytoplankton and even zooplankton (Aktan et al., 2008; Danovaro et al., 2009; Tüfekçi et al., 2010; Balkis et al., 2011; Yentur et al., 2013; Toklu-Alicli et al., 2020; Öztürk et al., 2021; Balk1s-Ozdelice et al., 2021).

The must understand the characteristics of microbial genes and their metabolic functions in mucilage. With metagenomic analysis, it is possible to obtain comprehensive genomic information about microbial structures and gene functions in various environmental samples. Functional gene characteristics of the microbial community can be discovered with KEGG, eggNOG and
CAZy databases (Fadiji \& Babalola 2020).In this study, metabolic diversity, microbial community structure and diverse antimicrobial resistance genes of mucilage were analyzed for the first time with a shotgun metagenomic approach.

\section{MATERIAL AND METHOD}

Sampling, DNA Extraction, Library Preparation and Sequencing: Mucilage samples were collected from the three different stations of the Dardanelles (Station 1: $40^{\circ} 15^{\prime} 22.53^{\prime \prime N}$, 26 $40^{\prime} 43.58^{\prime \prime} \mathrm{E}$; Station 2: 40¹0'59.21"N, $26^{\circ} 37^{\prime} 81.17^{\prime \prime E}$; Station 3: $40^{\circ} 11^{\prime} 15.67^{\prime \prime N}, 26^{\circ} 39^{\prime} 90.81^{\prime \prime E}$ ) in April 2021. The overview of the sampling points is given in the published paper by Yilmaz et al. (2021). The accumulation of the mucilage in Dardanles was observed on these sampling stations during the sampling period. A $5 \mathrm{~L}$ Niskin bottle was used for sampling according to the ISO 5667-9 method by the Turkish Coast Guard ship in Çanakkale (ISO 5667-9, 1992). Mucilage samples were centrifuged at $10,000 \times \mathrm{g}$ for $10 \mathrm{~min}$ and separated. Accumulated fresh samples were immedietaly used for DNA extraction. According to the manufacturer's instructions, genomic DNA was extracted from the mucilage samples using GeneMATRIX Soil DNA Purification Kit (EURx Poland). DNA degradation and concentration were monitored using spectrometry (OD260/280), fluorometry (Qubit ${ }^{\circledR} \quad 2.0 \quad$ Flurometer), and $1 \%$ agarose gel electrophoresis. DNA contents above $1 \mu \mathrm{g}$ was used to construct the library. Metagenomic analyses were performed by the BM Labosis laboratory (Ankara, Turkey). Briefly, sequencing libraries were generated, and index codes were added using NEBNext ${ }^{\circledR}$ Ultra $^{\text {TM }}$ DNA Library Prep Kit for Illumina according to the manufacturer's guidelines. Fragments of the DNA sample fragmented to 350bp size by sonication were polished. After $\operatorname{Poly}(\mathrm{A})$ Tail was carried out, it was ligated with a full-length adapter for Illumina sequencing by PCR amplification. PCR products were purified with the AMPure XP system and quantified by realtime PCR. Library preparations were sequenced with the Illumina platform, and paired-end reads were generated. SOAP denovo (Version 2.21): http://soap.genomics.org.cn/soapdenovo.html, SoapAligner 
(Version: 2.21): http://soap.genomics.org.cn/soapaligner. html, MetaGeneMark ( Version: 2.10 ) http://exon.gatech.edu/GeneMark/ and CD-HIT (Version: 4.5.8): http://www.bioinformatics.org/cd-hit/ software were used to process and analyze metagenomic sequence data.

\section{RESULTS}

Taxonomic Diversity of Microbial Communities: Figure 1 depicts a Krona (Ondov et al., 2011) visualization of microbial communities detected in April 2021 mucilage samples across the three sites. The dominant microbial communities at the phylum level were Bacteroidetes $(20.06 \%)$, Proteobacteria (13.68\%), Verrucomicrobia (6.25\%), Planctomycetes (3.02\%) and Cyanobacteria (2.5\%) (Figure 1). It is expected that Bacteroidetes is dominant in mucilage samples because species belonging to this phylum are generally known to live in symbiosis with algae (Bobrova et al., 2016). In addition, Bacteroidetes species can break down polymeric substances and use them as carbon and energy sources develop on detritus particles or algae cells (Fernández-Gómez, 2012). In this study, it was determined that proteobacteria, which is the second most dominant group, is a dominant phylum both in polluted and highly salty (Cortés-Lorenzo et al., 2014) environments and in marine environments (Qian et al., 2011; Polymenakou et al., 2020). In their study carried out in the Northern Adriatic Sea, Vojvoda et al. (2014) determined that Bacteroidetes, Cyanobacteria, and Proteobacteria groups were dominant in both mucilage and ambient water in December 2009 and August 2010.

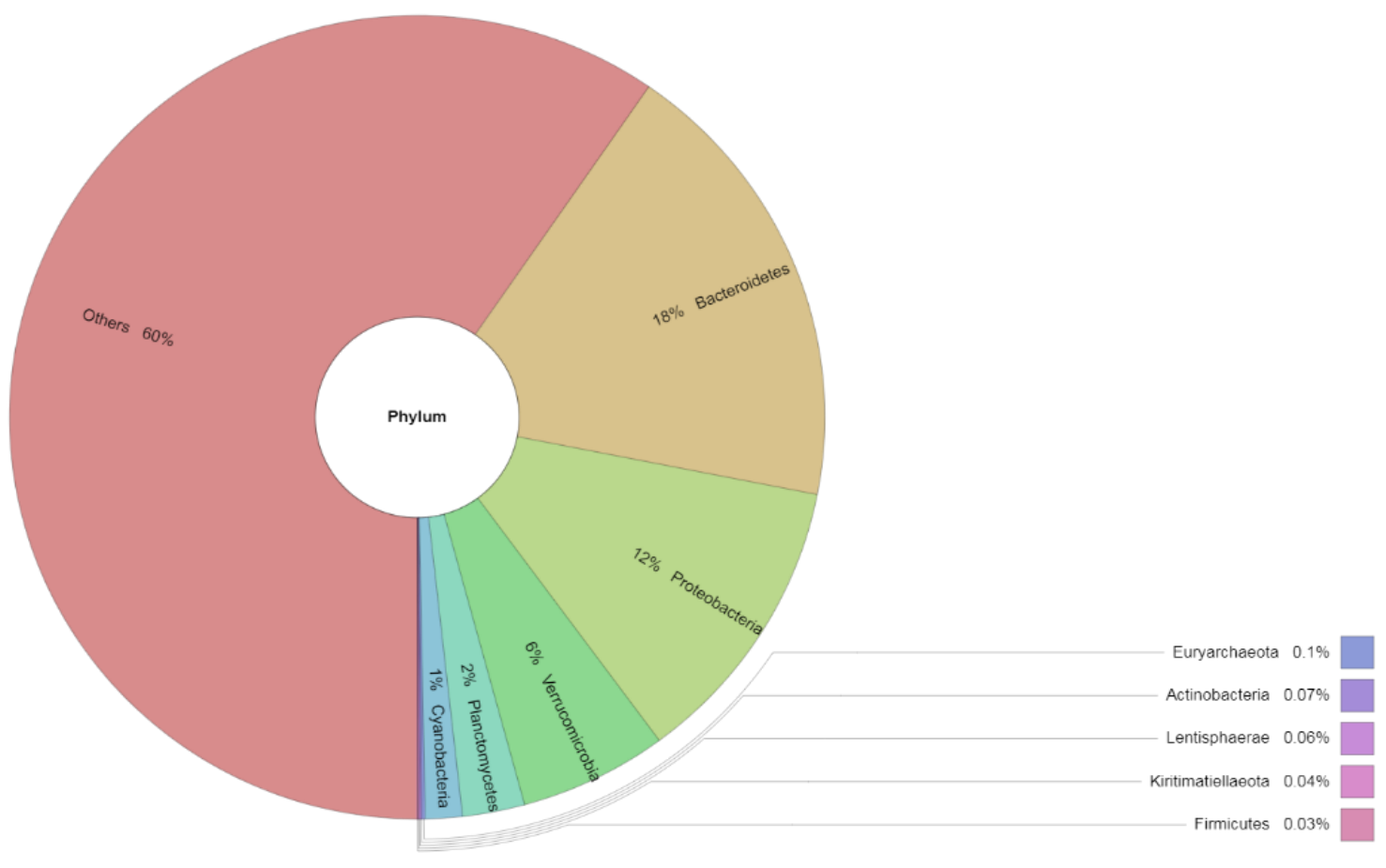

Station 1
This study reported that bacterial species belonging to the third most dominant phylum, verrucomicrobia, play an essential role in the biogeochemical cycle of carbon and anaerobic ammonium oxidation in the oceans (Freitas et al., 2012). Verrucomicrobia species have been isolated from a lake (Arnds et al., 2010; Chiang et al., 2018), soil (Bergmann et al., 2011; Zhou et al., 2017), seawater column (Bano \& Hollibaugh 2002; Yoon et al., 2007), and marine sediment (Urakawa et al., 1999; Yoon et al., 2008; Dalcin Martins et al., 2021).

Typically, planctomycetes are a rare or low-level group in the marine environment. It was reported in studies conducted in the Black Sea (Fuchsman et al., 2012) and Santa Barbara Channel (DeLong et al., 1993) that they are among the dominant bacterial groups in mucilage structure. Known for their complex organic matter decomposition properties in oxygen, some members of this phylum are known to be special decomposers of sulfated polysaccharides such as fucoidan, which can enable them to utilize the carbon produced by algae (Woebken et al., 2007; Bengtsson \& Øvreås, 2010.

In our study, the fourth most dense group was the Cyanobacteria phylum, with an average rate of $2.5 \%$. Although species belonging to this phylum are generally found in freshwater environments, climate change and anthropogenic pressure were also reported as factors leading to an increase in Cyanobacteria populations in marine environments (Bobrova et al., 2016). Similarly, Cyanobacteria members were detected extensively in mucilage in the Northeast Atlantic Ocean (Lampitt et al., 1993) and Sargasso Sea (Lundgreen et al., 2019). 


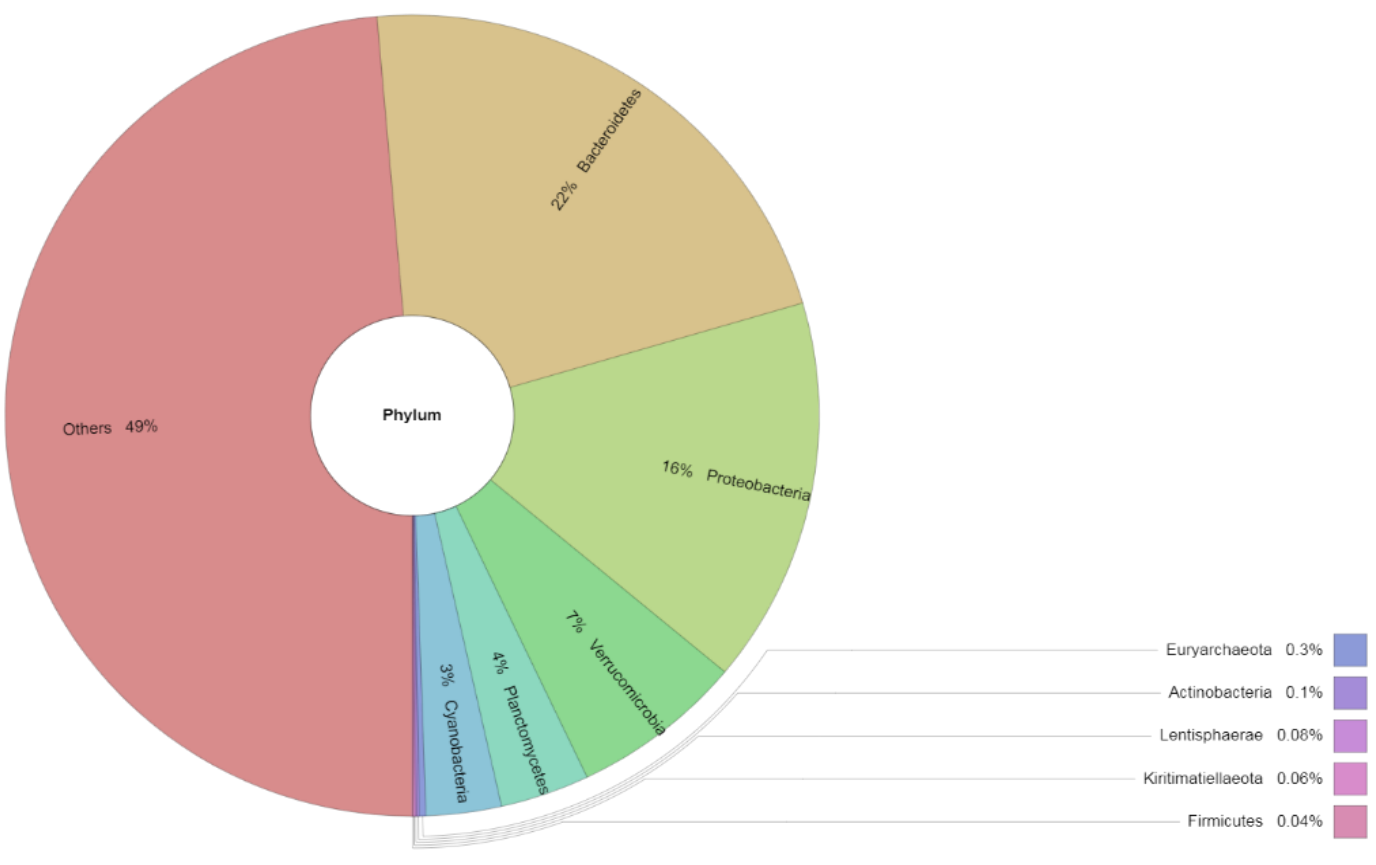

Station 2

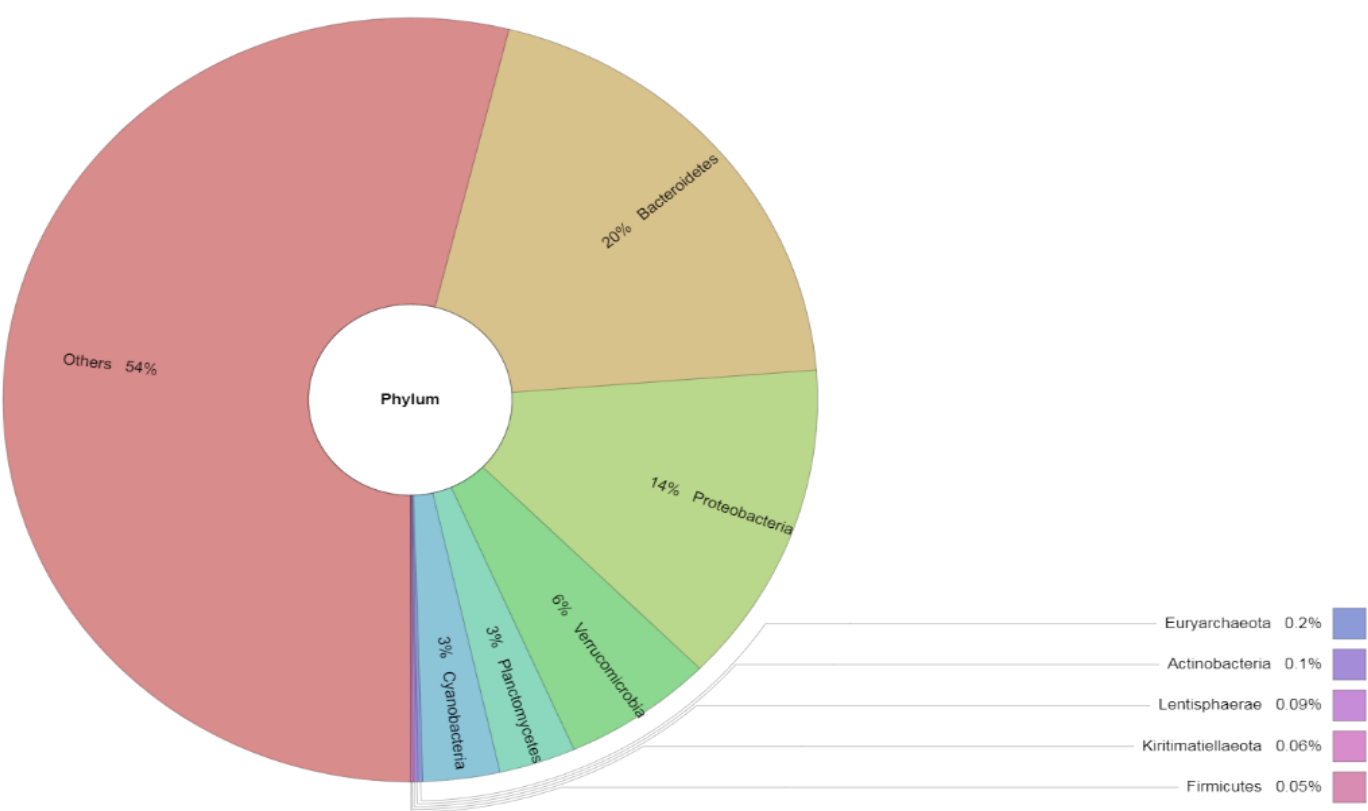

Station 3

Figure 1. Krona visualization. Microbial community compositions in the mucilage samples.

Metabolic Pathway Analysis of Mucilage Samples: Metabolic pathway analysis using KEGG revealed that most of the genes of mucilage samples were involved in unclassified $(73.86 \%)$ followed by metabolism $(14.45 \%)$, genetic information processing $(4.16 \%)$, environmental information processing $(2.57 \%)$, cellular processing $(1.88 \%)$, human diseases $(1.61 \%)$, and organismal systems $(1.47 \%)$ (Figure 2). These genes were enriched into 374 pathways of 6 KEGG A classes and 45 KEGG B classes (Figure 3).

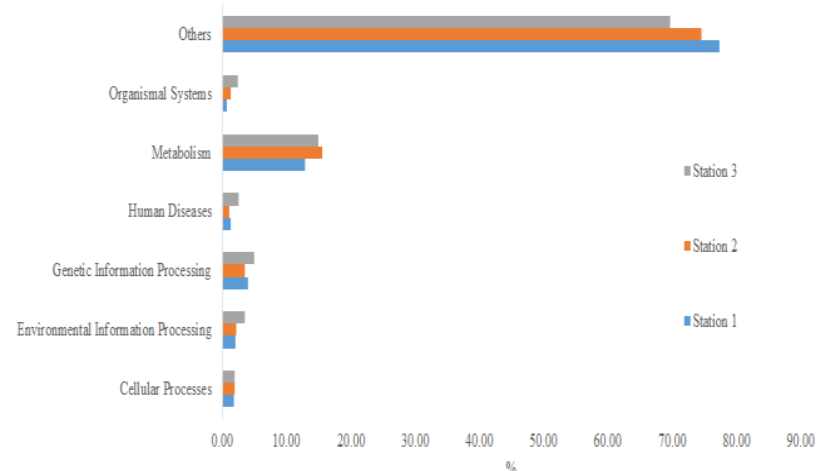

Figure 2. Distribution of the KEGG classification in mucilage samples. 


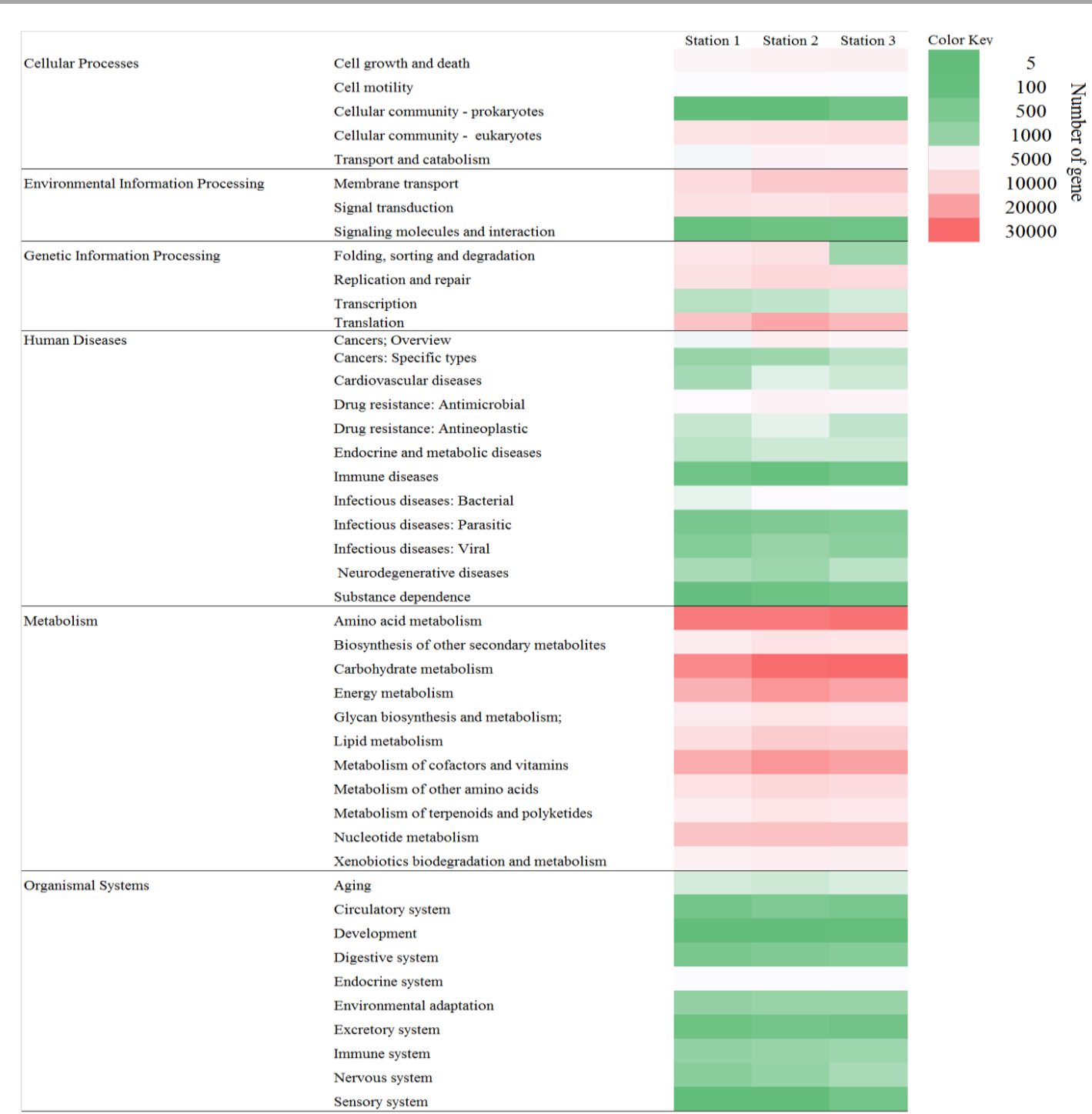

Figure 3. Heat map of mucilage samples KEGG pathway annotations.

As shown in Figure 4, the category glycoside hydrolases corresponded to the highest number of genes, and the category polysaccharide lyases corresponded to the lowest number of genes.

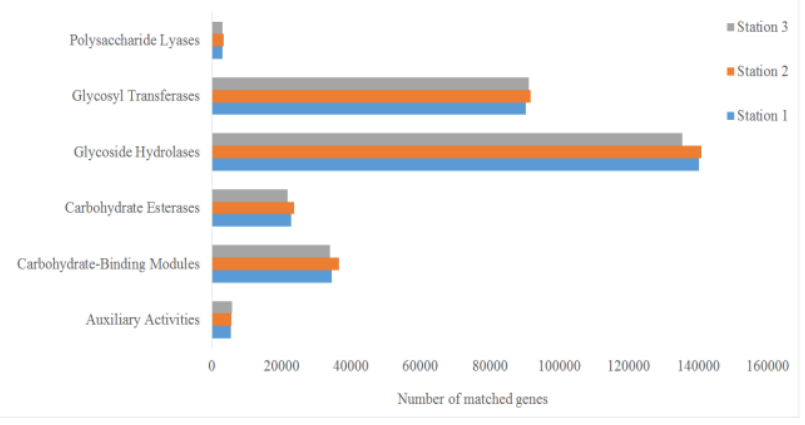

Figure 4. Number of matched genes of carbohydrates.

The eggNOG database annotation results are shown in Figure 5. As a result, the main functions of the genes included carbohydrate transport and metabolism, amino acid transport and metabolism, information storage and processing, and energy production and conversion. These four functional types were involved in main metabolism in various environmental samples (Meneghine et al., 2017; Zhao et al., 2019; Raiyani \& Singh 2020). Previous studies showed that carbohydrates and proteins were significant fractions of mucilage (Mecozzi et al., 2001; Mecozzi et al., 2004). The carbohydrate and protein rich contents can contribute to the enrichment of the carbohydrate and amino acid metabolism genes, so that large amounts of carbon and nitrogen can be utilized and converted within the mucilage structure.

The $d f r A 3$ gene was the most prevalent $(20.36 \%)$ followed by CRP (18.17\%), PmrE (14.92\%), rpoB2 (11.17\%), SoxR (7.49\%), AbeS (6.83\%), baeR (5.22\%), PmrF (3.70\%), dfrA22 (2.20\%), dfrA26 (1.76\%), dfrA20 (1.63\%), gols (1.26\%), CAT (1.03\%), mtrA (1.01\%), TMB-1 (0.64\%), novA (0.64\%), dfrK (0.59\%), vanXB (0.48\%), dfrG $(0.39 \%)$, FosC2 $(0.31 \%)$, and MexA $(0.20 \%)$ genes (Figure $6)$. The distribution of antibiotic classes detected in each station (S1: Station 1, S2: Station 2, S3: Station 3) by Circos (Krzywinski et al., 2009) was shown in Figure 7. 


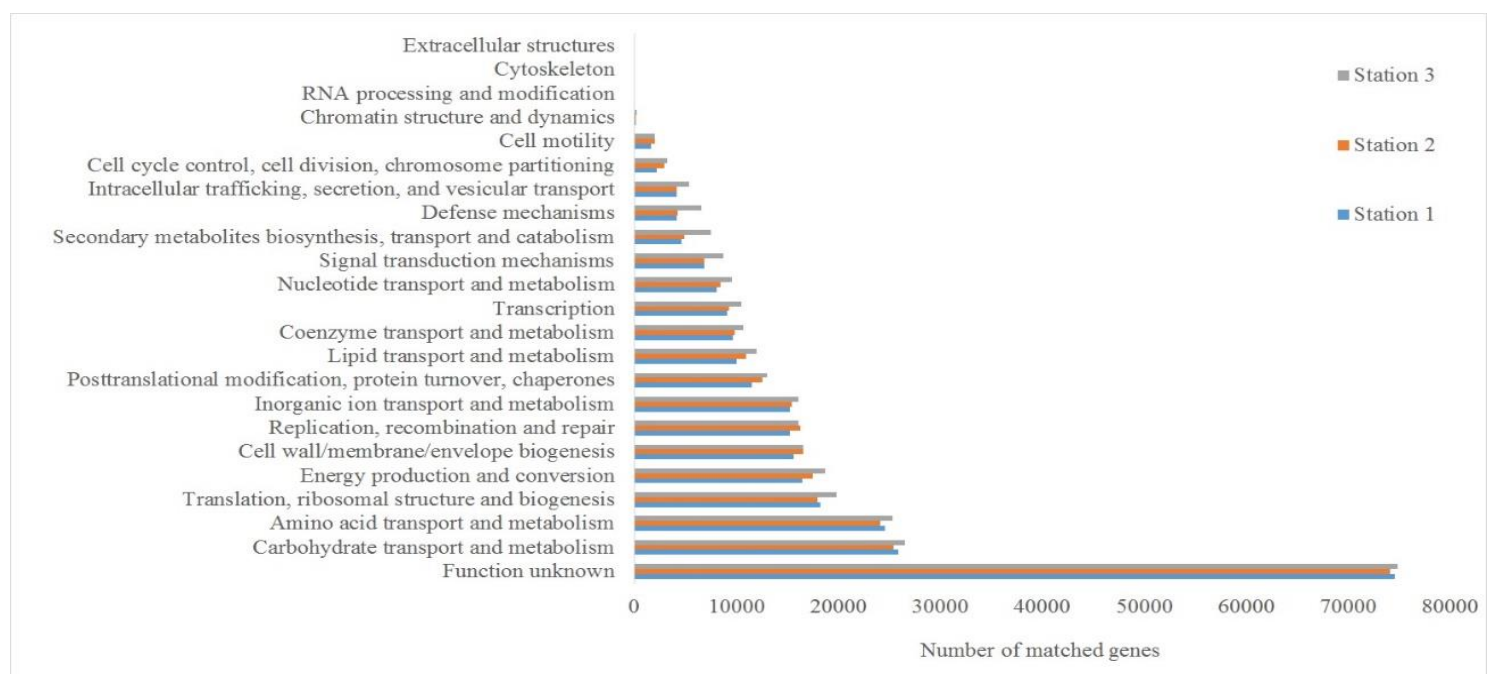

Figure 5. Distribution of the functional genes in mucilage samples.

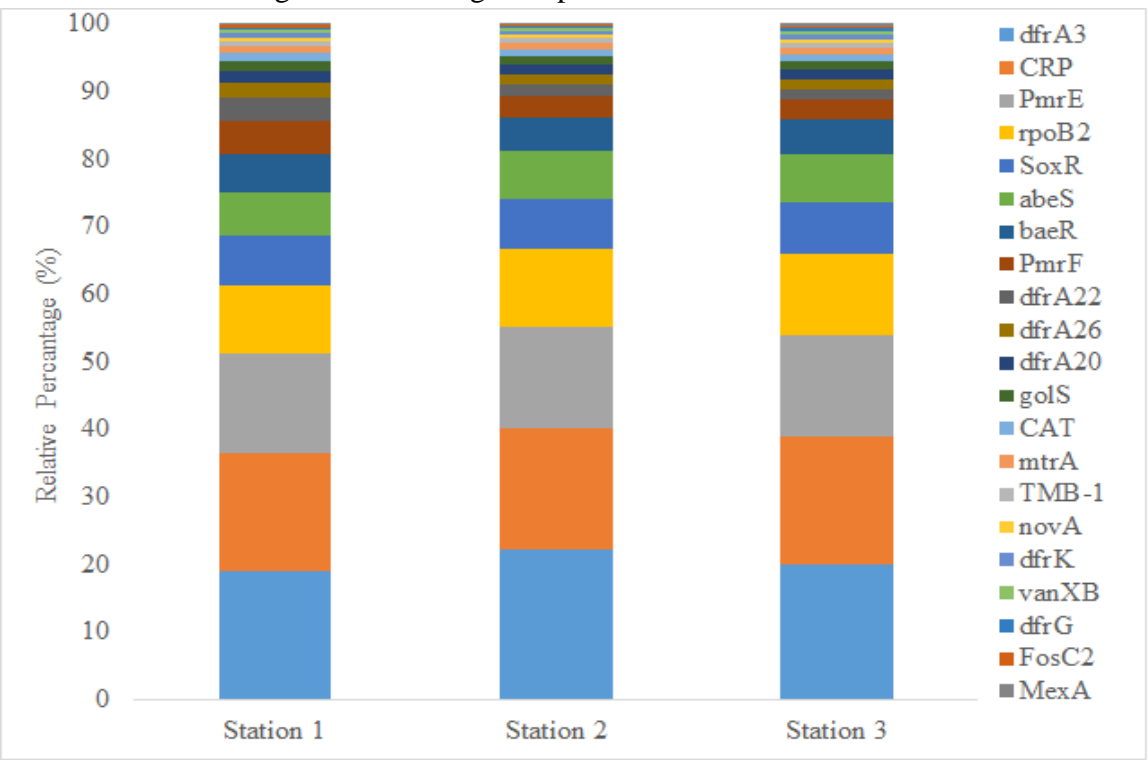

Figure 6. The abundance of resistance genes in mucilage samples.

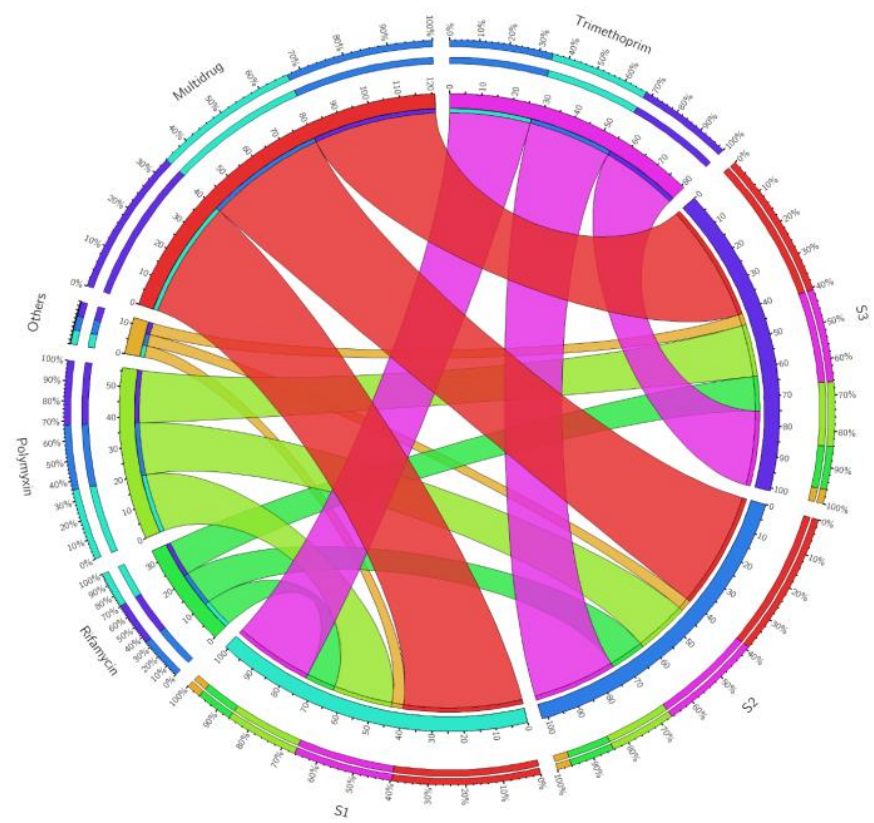

Figure 7. Circos representation of the dominant antibiotic classes. 
The metagenomic analysis is widely used in order to quantitatively analyze the occurrence, abundance and diversity of ARGs in samples obtained from marine or freshwater environments and to reveal metabolic diversity and microbial community structures (Pinnell \& Turner 2019; Quillaguamán et al., 2021; Wang et al., 2021). However, a similar study on mucilage structure has not been found in the literature. In this study, the functional diversity of the microbiome in mucilage samples was analyzed for the first time. The results were found to be similar to those of marine water (Gilbert et al., 2008), Amazonian geothermal spring (Paul et al., 2016), biofloc (Meenakshisundaram et al., 2021) and mud (Zhang et al., 2019) samples.

In addition, 21 resistance genes were detected in mucilage samples collected from 3 different stations. Antibiotic resistance gene (ARG) types mainly included the resistance genes of multidrug $(40.19 \%)$, trimethoprim (26.93\%), polymyxin (18.62\%), rifamycin $(11.17 \%)$, chloramphenicol $(1.03 \%)$, aminocoumarin $(0.64 \%)$, betalactamase $(0.64 \%)$, fosfomycin $(0.31 \%)$, and vancomycin $(0.48 \%)$.

It is noteworthy that the multi-antibiotic resistance rate is approximately $40 \%$. We consider that the obtained results are related to antibiotics used extensively in human and animal medicine. Trimethoprim (Kılıç \& Yenilmez, 2019), which is among the top 5 antibiotics prescribed in Turkey, is used to treat enteric, respiratory, skin and urinary tract infections (Huovinen et al., 1995).

In recent years, although the use of polymyxin has been recommended to prevent multi-resistant infections caused by Pseudomonas spp. and Acinetobacter spp., it has also been reported that there is a risk of developing resistance (Turgut, 2017).

Rifamycin is used to treat tuberculosis, leprosy and AIDS-related mycobacterial infections. Still, Rifamycin resistance develops very rapidly, and it is recommended to be applied with other agents to overcome this resistance (Floss \& Yu, 2005).

Chloramphenicol used in treating superficial eye infections such as bacterial conjunctivitis and otitis externa (Oong \& Tadi, 2021) is currently used more in animal medicine than human medicine (Grenni et al., 2018). The FAO/WHO Expert Committee on Food Additives (JECFA) concluded that chloramphenicol could cause genetic damage and possibly cause cancer (FAO, 2002).

In this study, beta-lactamase and fosfomycin, which are antibiotics that showed resistance below $1 \%$, were among the antibiotics most frequently prescribed by family physicians throughout Turkey (Isli et al., 2020). In this study, vancomycin showing a low resistance rate $(0.48 \%)$ is used to treat Enterococcus infections, standing out as hospital-associated pathogens with multiple antibiotic resistance. The vancomycin resistance of Enterococcus faecalis and Enterococcus faecium strains isolated in Turkey in 2017 was determined as $1 \%$ and $13 \%$, respectively (WHO, 2018).

In a comprehensive study conducted in the North Pacific, South Sea of Korea, Indian Ocean, Sargasso Sea, Arctic Ocean, Bay of British Columbia, and the Gulf of Mexico, it was noteworthy that multidrug and aminocoumarin resistance was found in all viromes rather than being in excess of a percent (Calero-Cáceres \& Balcázar, 2019).

\section{CONCLUSION}

In conclusion, it was determined in this study that the findings obtained from metagenomic analyzes on mucilage samples collected from 3 different stations were similar. Antibiotic-resistant bacteria in mucilage can adhere to human skin during swimming, fishing, water sports etc., enter the body through the nose and mouth, and transfer genetic information to the bacteria in contact areas in the human body. Thus, this situation is risky in public health, and necessary precautions should be taken. In the light of these findings, it has been observed that there is a need for more detailed studies with samples to be taken at different times and from depths in the future.

\section{ACKNOWLEDGEMENTS}

The authors like to thank the Turkish Coast Guard Command in Çanakkale for their helpful collaboration in sampling.

\section{REFERENCES}

Aktan, Y., Dede, A., \& Çiftci, P.S. (2008). Mucilage event associated with diatoms and dinoflagellates in Sea of Marmara, Turkey, Harmful Algae News, 36, 1-3.

Arnds, J., Knittel, K., Buck, U., Winkel, M., \& Amann, R. (2010). Development of a 16S rRNA-targeted probe set for Verrucomicrobia and its application for fluorescence in situ hybridization in a humic lake. Systematic and Applied Microbiology, 33(3), 139-148. DOI: 10.1016/j.syapm.2009.12.005

Balkis, N., Atabay, H., Türetgen, I., Albayrak, S., Balkis, H., \& Tüfekçi, V. (2011). Role of singlecelled organisms in mucilage formation on the shores of Büyükada Island (the Marmara Sea). Journal of the Marine Biological Association of the United Kingdom, 91(4), 771-781. DOI: $10.1017 / \mathrm{S} 0025315410000081$

Balkıs-Ozdelice, N., Durmuş, T., \& Balcı, M. (2021). “A Preliminary Study on the Intense Pelagic and Benthic Mucilage Phenomenon Observed in the 
Sea of Marmara", International Journal of Environment and Geoinformatics, 8(4), 414-422. DOI: $10.30897 /$ ijegeo.954787

Bano, N. \& Hollibaugh, J.T. (2002). Phylogenetic composition of bacterioplankton assemblages from the Arctic Ocean. Applied and Environmental Microbiology, 68(2), 505-518. DOI: 10.1128/AEM.70.2.781-789.2004

Bengtsson, M.M. \& Øvreås, L. (2010). Planctomycetes dominate biofilms on surfaces of the kelp Laminaria hyperborea. BMC Microbiology, 10(1), 1-12. DOI: 10.1186/1471-2180-10-261

Bergmann, G.T., Bates, S.T., Eilers, K.G., Lauber, C.L., Caporaso, J.G., Walters, W.A., Knight, R. \& Fierer, N. (2011). The under-recognized dominance of Verrucomicrobia in soil bacterial communities. Soil Biology and Biochemistry, 43(7), 1450-1455. DOI: 10.1016/j.soilbio.2011.03.012

Bobrova, O.Y., Kristoffersen, J.B., Oulas, A. \& Ivanytsia, V.O. (2016). Metagenomic 16s rRNA investigation of microbial communities in the Black Sea estuaries in South-West of Ukraine. Acta Biochimica Polonica 63(2), 315-319. DOI: 10.18388/abp.2015_1145

Calero-Cáceres, W. \& Balcázar, J.L. (2019). Antibiotic resistance genes in bacteriophages from diverse marine habitats. Science of the Total Environment, 654, 452-455. DOI: 10.1016/j.scitotenv.2018.11.166

Chiang, E., Schmidt, M.L., Berry, M.A., Biddanda, B.A., Burtner, A., Johengen, T.H., Palladino, D. \& Denef, V.J. (2018). Verrucomicrobia are prevalent in north-temperate freshwater lakes and display class-level preferences between lake habitats. PLoS One, 13(3), e0195112. DOI: 10.1371/journal.pone.0195112

Cortés-Lorenzo, C., Sipkema, D., Rodríguez-Díaz, M., Fuentes, S., Juárez-Jiménez, B., Rodelas, B., Simidt, R. \& González-López, J. (2014). Microbial community dynamics in a submerged fixed bed bioreactor during biological treatment of saline urban wastewater. Ecological Engineering, 71, 126-132. DOI: 10.1016/j.ecoleng.2014.07.025

Dalcin Martins, P., de Jong, A., Lenstra, W.K., van Helmond, N. A., Slomp, C.P., Jetten, M.S., Welte, C.U. \& Rasigraf, O. (2021). Enrichment of novel Verrucomicrobia, Bacteroidetes, and Krumholzibacteria in an oxygen-limited methaneand iron-fed bioreactor inoculated with Bothnian Sea sediments. MicrobiologyOpen, 10(1), e1175. DOI: 10.1101/2020.09.22.307553

Danovaro, R., Fonda Umani, S. \& Pusceddu, A. (2009). "Climate change and the potential spreading of marine mucilage and microbial pathogens in the Mediterranean Sea", PLoS One, 4(9), 7006. DOI: 10.1371/journal.pone.0007006

DeLong, E.F., Franks, D.G. \& Alldredge, A.L. (1993). Phylogenetic diversity of aggregate-attached vs. free-living marine bacterial assemblages.
Limnology and Oceanography, 38(5), 924-934. DOI: $10.4319 /$ lo.1993.38.5.0924

FAO, (2002). FAO urges countries to discontinue the use of chloramphenicol in animal production. 24/01/2002

Fadiji, A.E. \& Babalola, O.O. (2020). Metagenomics methods for the study of plant-associated microbial communities: a review. Journal of Microbiological Methods, 170, 105860. DOI: 10.1016/j.mimet.2020.105860

Fernández-Gómez, B. (2012). Ecology of marine Bacteroidetes: a genomics approach. Ph.D. thesis. Universidad de Las Palmas de Gran Canaria, Las Palmas de Gran Canaria, Spain.

Floss, H.G. \& Yu, T.W. (2005). Rifamycin mode of action, resistance, and biosynthesis. Chemical Reviews, 105(2), 621-632. DOI: 10.1021/cr030112j

Freitas, S., Hatosy, S., Fuhrman, J.A., Huse, S.M., Welch, D.B.M., Sogin, M.L. \& Martiny, A.C. (2012). Global distribution and diversity of marine Verrucomicrobia. The ISME Journal, 6(8), 1499-1505. DOI: 10.1038/ismej.2012.3

Fuchsman, C. A., Staley, J. T., Oakley, B. B., Kirkpatrick, J. B. \& Murray, J. W. (2012). Free-living and aggregate-associated Planctomycetes in the Black Sea. FEMS Microbiology Ecology, 80(2), 402-416. DOI: 10.1111/j.1574-6941.2012.01306.x

Giani, M., Berto, D., Zangrando, V., Castelli, S., Sist, P. \& Urbani, R. (2005). Chemical characterization of different typologies of mucilaginous aggregates in the Northern Adriatic Sea. Science of the Total Environment, 353, 232-246. DOI: 10.1016/j.scitotenv.2005.09.027

Gilbert, J. A., Field, D., Huang, Y., Edwards, R., Li, W., Gilna, P., \& Joint, I. (2008). Detection of large numbers of novel sequences in the metatranscriptomes of complex marine microbial communities. PloS One, 3(8), e3042. DOI: 10.1371/journal.pone.0003042

Grenni, P., Ancona, V. \& Caracciolo, A. B. (2018). Ecological effects of antibiotics on natural ecosystems: A review. Microchemical Journal, 136, 25-39. DOI: 10.1016/j.microc.2017.02.006

Huovinen, P., Sundström, L., Swedberg, G. \& Sköld, O. (1995). Trimethoprim and sulfonamide resistance. Antimicrobial Agents and Chemotherapy, 39(2), 279-289. DOI: 10.1128/aac.39.2.279

Isli, F., Aksoy, M., Aydıngoz Emre, S. \& Kadı E. (2020). Rational Use of Antibiotics By Family Physicians in Turkey During Primary Healthcare Service: A CrossSectional Analysis Through The Prescription Information System. TJFMPC, 14(1), 87-95. DOI: $10.21763 / \mathrm{tjfmpc} .618125$

ISO 5667-9. (1992). International Standards Organization (ISO), Water quality Sampling Part 9: Guidance on sampling from marine waters, Geneva, Switzerland

Krzywinski, M., Schein, J., Birol, I., Connors, J., Gascoyne, R., Horsman, D. \& Marra, M. A. 
(2009). Circos: an information aesthetic for comparative genomics. Genome research, 19(9), 1639-1645. DOI: 10.1101/gr.092759.109

Kılıç, E. \& Yenizlmez, F. (2019). Türkiye ve AB Ülkelerinde Antibiyotik Kullanımı, Antibiyotik Direnci ve Dış Ticaret Dengesi Üzerine Bir Değerlendirme. ESTÜDAM Halk Să̆lı̆̆ Dergisi, 4(1), 45-54. DOI: 10.35232/estudamhsd.503456

Lampitt, R. S., Wishner, K. F., Turley, C. M. \& Angel, M. V. (1993). Marine snow studies in the Northeast Atlantic Ocean: distribution, composition and role as a food source for migrating plankton. Marine Biology, 116(4), 689702. https://doi.org/10.1007/BF00355486

Lundgreen, R. B., Jaspers, C., Traving, S. J., Ayala, D. J., Lombard, F., Grossart, H. P. \& Riemann, L. (2019). Eukaryotic and cyanobacterial communities associated with marine snow particles in the oligotrophic Sargasso Sea. Scientific Reports, 9(1), 1-12. DOI: 10.1038/s41598-019-45146-7

Meneghine, A.K., Nielsen, S., Varani, A.M., Thomas, T. \& Carareto Alves, L.M. (2017). Metagenomic analysis of soil and freshwater from zoo agricultural area with organic fertilization. PLoSOne, 12, e0190178.

Mecozzi, M., Acquistucci, R., Di Noto, V., Pietrantonio, E., Amici, M. \& Cardarilli, D. (2001). Characterization of mucilage aggregates in Adriatic and Tyrrhenian Sea: structure similarities between mucilage samples and the insoluble fractions of marine humic substance. Chemosphere, 44(4), 709-720.

Meccozi, M. \& Pápai, Z. (2004). Application of curve fitting in thin-layer chromatography-flame ionization detection analysis of the carbohydrate fraction in marine mucilage and marine snow samples from Italian Seas. Journal of Chromatographic Science, 42(5), 268-274.

Meenakshisundaram, M., Sugantham, F., Muthukumar, C. \& Chandrasekar, M.S. (2021). Metagenomic characterization of biofloc in the grow-out culture of Genetically Improved Farmed Tilapia (GIFT). Aquaculture Research, 59(9), 4249-4262. DOI: 10.1111/are.15263

Ondov, B.D., Bergman, N.H., \& Phillippy, A.M. (2011). Interactive metagenomic visualization in a Web browser. BMC Bioinformatics, 12(1), 1-10. DOI: 10.1186/1471-2105-12-385

Oong, G.C. \& Tadi, P. (2021). Chloramphenicol. StatPearls (Last Update: July 9, 2021). https://www.ncbi.nlm.nih.gov/books/NBK55596 6/

Öztürk, İ., Yanalak, M., Arslan, E., Koyuncu, İ., Dülekgürgen, E., Erşahin, M.E. \& Türken, T. 2021. "Marmara Denizi'nde Deniz Salyası Sorunu İle İlgili Görüş Ve Öneriler”, İTÜ Raporu, İstanbul. DOI: 10.1186/1471-2105-12-385

Paul, S., Cortez, Y., Vera, N., Villena, G. K. \& Gutiérrez-Correa, M. (2016). Metagenomic analysis of microbial community of an
Amazonian geothermal spring in Peru. Genomics data, 9, 63-66. DOI: 10.3232/SJSS.2019.V9.N1.01

Pinnell, L. J. \& Turner, J. W. (2019). Shotgun metagenomics reveals the benthic microbial community response to plastic and bioplastic in a coastal marine environment. Frontiers in Microbiology, 10, 1252 . DOI: 10.3389/fmicb.2019.01252

Polymenakou, P. N., Nomikou, P., Mandalakis, M., Kilias, S., Kotoulas, G., Kyrpides, N. C. \& Magoulas, A. (2020). Microbial Benthic Communities in the Aegean Sea. In: The Handbook of Environmental Chemistry. Springer, Berlin, Heidelberg. 1-31 p, Springer: Berlin, Heidelberg. DOI: 10.1007/698_2020_685

Raiyani, N. M. \& Singh, S.P. (2020). Taxonomic and functional profiling of the microbial communities of Arabian Sea: a metagenomics approach. Genomics, 112(6), 4361-4369.

Qian, P.Y., Wang, Y., Lee, O.O., Lau, S.C., Yang, J., Lafi, F.F. \& Wong, T.Y. (2011). Vertical stratification of microbial communities in the Red Sea revealed by $16 \mathrm{~S}$ rDNA pyrosequencing. The ISME Journal, 5(3), 507-518. DOI: 10.1038/ismej.2010.112

Quillaguamán, J., Guzmán, D., Campero, M., Hoepfner, C., Relos, L., Mendieta, D., Higdon, S.M., Eid, D. \& Fernández, C. E. (2021). The microbiome of a polluted urban lake harbors pathogens with diverse antimicrobial resistance and virulence genes. Environmental Pollution, 273, 116488. DOI: 10.1016/j.envpol.2021.116488

Turgut, H., (2017). Polimiksinler (Kolistin ve Polimiksin B). Turkiye Klinikleri Infectious Diseases-Special Topics. $\quad 10(1), \quad 106-109 . \quad$ DOI: $10.32322 / \mathrm{jhsm} .456990$

Tüfekçi, V., Balkis, N., Beken, C. P., Ediger, D. \& Mantikci, M. (2010). Phytoplankton composition and environmental conditions of the mucilage event in the Sea of Marmara. Turkish Journal of Biology, 34(2), 199-210.

Fonda-Umani, S., Ghirardelli, E. \& Specchi, M. (1989). Gli episodi di" mare sporco" nell'Adriatico dal 1729 ai giorni nostri. Regione Autonoma FriuliVenezia Giulia. Direzione Regionale Ambiente, Trieste, p 178. DOI: 10.1371/journal.pone.0007006

Urakawa, H., Kita-Tsukamoto, K. \& Ohwada, K. (1999). Microbial diversity in marine sediments from Sagami Bay and Tokyo Bay, Japan, as determined by $16 \mathrm{~S}$ rRNA gene analysis The DDBJ accession numbers for the sequences reported in this paper are AB022607-AB022642. Microbiology, 145(11), 3305-3315. DOI: 10.1099/00221287-145-11-3305

Vojvoda, J., Lamy, D., Sintes, E., Garcia, J. A., Turk, V., \& Herndl, G. J. (2014). Seasonal variation in marine-snow-associated and ambient-water prokaryotic communities in the northern Adriatic Sea. Aquatic Microbial Ecology, 73(3), 211-224. DOI: $10.3389 /$ fmicb.2020.584222 
Wang, Y., Liao, S., Gai, Y., Liu, G., Jin, T., Liu, H., Gram, L., Strube, M. L., Fan, G., Sahu, S. K., Liu, S., Gan, S., Xie, Z., Kong, L., Zhang, P., Liu, X. \& Wang, D. Z. (2021). Metagenomic Analysis Reveals Microbial Community Structure and Metabolic Potential for Nitrogen Acquisition in the Oligotrophic Surface Water of the Indian Ocean. Frontiers in Microbiology, 12, 229. DOI: 10.3389/fmicb.2021.518865

WHO (2018). WHO, World Health Organization. Central Asian and Eastern European Surveillance of Antimicrobial Resistance: Annual Report 2018.

Woebken, D., Teeling, H., Wecker, P., Dumitriu, A., Kostadinov, I., DeLong, E.F., Amann, R. \& Glöckner, F.O. (2007). Fosmids of novel marine Planctomycetes from the Namibian and Oregon coast upwelling systems and their crosscomparison with planctomycete genomes. The ISME Journal, 1(5), 419-435.

Yentur, R.E., Büyükateş, Y., Özen, Ö. \& Altın, A. (2013). The environmental and socio-economical effects of a biologic problem: Mucilage. Marine Science and Technology Bulletin, 2(2), 13-15.

Yılmaz, S., Küçüker, M.A. \& Kahraman Yılmaz, D. (2021). Metagenomic characterization of planktonic communities during a mucilage event in the Çanakkale Strait (Dardanelles), Turkey. Journal of Anatolian Environmental and Animal Sciences, 6(3), 421-427.

Yoon, J., Yasumoto-Hirose, M., Matsuo, Y., Nozawa, M., Matsuda, S., Kasai, H. \& Yokota, A. (2007). Pelagicoccus mobilis gen. nov., sp. nov., Pelagicoccus albus sp. nov. and Pelagicoccus litoralis sp. nov., three novel members of subdivision 4 within the phylum 'Verrucomicrobia', isolated from seawater by in situ cultivation. International Journal of Systematic and Evolutionary Microbiology, 57(7), 1377-1385. DOI: 10.1099/ijs.0.64970-0

Yoon, J., Matsuo, Y., Adachi, K., Nozawa, M., Matsuda, S., Kasai, H. \& Yokota, A. (2008). Description of Persicirhabdus sediminis gen. nov., sp. nov., Roseibacillus ishigakijimensis gen. nov., sp. nov., Roseibacillus ponti sp. nov., Roseibacillus persicicus sp. nov., Luteolibacter pohnpeiensis gen. nov., sp. nov. and Luteolibacter algae sp. nov., six marine members of the phylum 'Verrucomicrobia', and emended descriptions of the class Verrucomicrobiae, the order Verrucomicrobiales and the family Verrucomicrobiaceae. International Journal of Systematic and Evolutionary Microbiology, 58(4), 998-1007. DOI: 10.1099/ijs.0.65520-0

Zhang, L., Shen, Z., Fang, W. \& Gao, G. (2019). Composition of bacterial communities in municipal wastewater treatment plant. Science of the Total Environment, 689, 1181-1191. DOI: 10.1016/j.scitotenv.2019.06.432

Zhou, Y., Zhu, H., Fu, S., \& Yao, Q. (2017). Variation in soil microbial community structure associated with different legume species is greater than that associated with different grass species. Frontiers in Microbiology, 8, $1007 . \quad$ DOI: 10.3389/fmicb.2017.01007

Zhao, H., Yan, B., Mo, S., Nie, S., Li, Q., Ou, Q. \& Jiang, C. (2019). Carbohydrate metabolism genes dominant in a subtropical marine mangrove ecosystem revealed by metagenomics analysis. Journal of Microbiology, 57(7), 575-586. 